\section{Prolegómenos}

\section{Derecho y Valores}

Prolegómenos. Derechos y Valores

ISSN: 0121-182X

derechos.valores@umng.edu.co

Universidad Militar Nueva Granada

Colombia

Lorca Martín de Villodres, María Isabel

DERECHO Y LITERATURA: GÉNERO, LIBERTAD Y JUSTICIA EN LA OBRA DRAMÁTICA DE

GARCÍA LORCA

Prolegómenos. Derechos y Valores, vol. XV, núm. 30, julio-diciembre, 2012, pp. 119-140

Universidad Militar Nueva Granada

Bogotá, Colombia

Disponible en: http://www.redalyc.org/articulo.oa?id=87625443007

- Cómo citar el artículo

Número completo

- Más información del artículo

- Página de la revista en redalyc.org

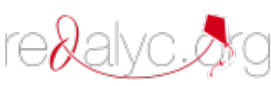

Sistema de Información Científica

Red de Revistas Científicas de América Latina, el Caribe, España y Portugal

Proyecto académico sin fines de lucro, desarrollado bajo la iniciativa de acceso abierto 


\title{
DERECHO Y LITERATURA: GÉNERO, LIBERTAD Y JUSTICIA EN LA OBRA DRAMÁTICA DE GARCÍA LORCA*
}

\author{
María Isabel Lorca Martín de Villodres**
}

Fecha de Recibido: 28 de agosto de 2012

Fecha de Aprobado: 15 de octubre de 2012

Artículo de Reflexión

Forma de citación: Lorca, M. I. (2012). Derecho y Literatura: Género, Libertad y Justicia en la obra dramática de García Lorca. Revista Prolegómenos. Derechos y Valores, 15, 30, 119-140.

\author{
"¿Dónde está la razón de la Justicia?" \\ García Lorca, F., Mariana Pineda, 1925. \\ Estampa tercera, Escena V.
}

\begin{abstract}
Resumen
Desde hace ya algún tiempo y especialmente desde el sendero iusfilosófico, se abre paso con fuerza una tendencia que subraya la interacción existente entre Derecho y Literatura. Se parte de una concepción jurídica menos dogmática y formalista, en donde el Derecho es contemplado como un fenómeno esencialmente cultural, producto de la libertad humana creadora. Es concepción más abierta al enriquecimiento y contacto con otros campos de expresión cultural en donde, igualmente, se manifiestan los valores propios de la comunidad política. En la fecunda obra dramática del poeta de la Generación del 27, Federico García Lorca, encontramos el tratamiento de cuestiones de especial relevancia desde el punto de vista sociológico y filosófico-jurídico. Aspectos tales como el papel de la mujer, su diferencia con el rol asumido tradicionalmente por el varón, su ansia de libertad y su necesidad de escapar de los férreos convencionalismos sociales que asfixian su existencia cotidiana, así como un sentimiento profundo delajusticia natural que contrasta con lo justo legal. Todos ellos son aspectos que vertebran de forma trascendental la obra dramática lorquiana.
\end{abstract}

\section{Palabras clave}

Derecho, Literatura, Género, Libertad, Dignidad, Honor, Justicia.

Artículo de reflexión (documento que presenta resultados de investigación no finalizada).

* La doctora María Isabel Lorca Martín de Villodres es Profesora Titular de Filosofía del Derecho, en la Facultad de Derecho de la Universidad de Málaga (España), y autora de varias publicaciones. Es asimismo, Académica Correspondiente de la Real Academia de Jurisprudencia y Legislación de Madrid. 


\title{
LAW AND LITERATURE: GENDER, FREEDOM AND JUSTICE IN GARCIA LORCA'S DRAMATIC WORKS
}

\begin{abstract}
Since some time ago and especially from the ius-philosophical trail, a powerful trend that defends the relation between Law and Literature has opened its path. It begins as a less dogmatic and formal juridical conception, where law is studied as a cultural phenomenon created by human will. This conception is more open to contact and enrichment with other fields of cultural expression, where the values of the political community are also manifested. The work of Federico Garcia Lorca, who belonged to a group of Spanish poets called Generation of 27, deals with certain concepts that are relevant from a sociological and cultural point of view. Aspects like the female roles and its difference with the roles assumed traditionally by males, their need for freedom and from escape the rigid social convention that suffocate their existence, and a deep sense of natural justice that contrasts with the legal justice. All these aspects coordinate in a transcendental way all the works of Garcia Lorca.
\end{abstract}

\section{Keywords}

Law, Literature, Gender, Freedom, Dignity, Honour, Justice.

\section{DIREITO E LITERATURA: LIBERDADE, GÊNERO E JUSTIÇA NA OBRA DRAMATICA DE GARCIA LORCA}

\begin{abstract}
Resumo
Por algum tempo, especialmente desde que a trilha jusfilosófica, uma tendência que destaca a interação entre direito e literatura toma importância. Esta assume uma concepção jurídica dogmática e menos formalista, onde a lei é vista como um fenômeno essencialmente cultural, o produto da liberdade humana criativa. É um contato mais aberto com o enriquecimento e outras áreas de expressão cultural, que também se manifestam os valores da comunidade política. No drama do poeta prolífico da Geração de '27, Federico García Lorca, está o tratamento de questões de particular importância do ponto de vista da sociologia e filosófico-jurídica. Questões como o papel das mulheres, a diferença no papel tradicionalmente assumido pelo homem, seu desejo de liberdade ea necessidade de fugir das convenções sociais de ferro que sufocam a sua vida diária e um profundo sentido de justiça natural contrasta com o direito legal. Estes são todos os aspectos que formam a espinha dorsal transcendental da obra dramatica de Lorca.
\end{abstract}

\section{Palavras-chaves}

Direito, Literatura, Gênero, Liberdade, Dignidade, Honra, Justiça. 


\section{INTRODUCCIÓN: EL FECUNDO MARIDAJE DERECHO Y LITERATURA}

Resulta innegable el trasfondo antropológico que subyace en el Derecho, pues como se ha afirmado con acierto "en el sosiego espiritual del hombre hallamos el quicio en que encuentra fundamentación y justificación toda norma jurídica" (Lorca Navarrete, 2008, pág. 179). La sociedad constituye el propio origen de lo jurídico, siendo el ser humano su agente creador. El Derecho es una creación humana que surge de la necesidad de organizar armónicamente, pacíficamente, la convivencia entre seres sociables y políticos por naturaleza. El Derecho nace y se hace en la historia. En efecto, se ha apuntado certeramente que "el derecho es un elemento social que se encuentra inmerso en las fibras más íntimas de la comunidad a la que ordena. A ésta, le propone ideales de justicia (...,) porque una comunidad sin aspiraciones se marchita en la desesperación y hace inevitable la revolución o la guerra civil." (Botero Bernal, A., y Narváez Hernández, J.R., 2010, pág. 5).

Especialmente desde el sendero de la Filosofía del Derecho, se ha puesto de manifiesto con particular interés la vinculación existente entre Derecho y Literatura. Ambos sectores son expresión humana y poseen un evidente origen social; son muestra de la existencia de una sociedad civilizada, organizada y que cuenta ya con un nivel cultural apreciable. Baste recordar que el griego Estrabón en su Geografía (Hispania y Galia(Estrabón, 1995, pág. 42), nos hablaba acerca de los turdetanos, quienes eran"tenidos por más cultos de entre los iberos, puesto que no sólo utilizan escritura, sino que de sus antiguos recuerdos tienen también crónicas históricas, poemas y leyes versificadas de seis mil años..." (L. III, 1, 6, 27-28).

Sin duda, la expresión de "seis mil años" debiera entenderse como sinónimo de gran antigüedad, pero lo importante era que tales leyes estaban escritas, y lo estaban, además, en verso. El elemento de la escritura es, especialmente relevante, pues el hecho de que la legislación se plasme por escrito es factor esencial para alcanzar la seguridad jurídica en la vida de convivencia (Jongen, F. \& Lemmens, K., 2007, págs. 9-12). En definitiva, ambos, Derecho y Literatura, nacen de radicales necesidades antropológicas tales como, de un lado, alcanzar la seguridad y la justicia en el ámbito de lo jurídico, y, de otro, la expresión de sentimientos como el ansia de libertad, igualdad o amor, propios del ámbito literario.Derecho y Literatura nacen, en definitiva, como señalaban los miembros de la Escuela histórica del Derecho en Alemania, de una misma fuente creadora común, del Volksgeist (Puchta, 1828)1, y se valen también de comunes elementos, que son su vehículo de expresión por excelencia: la palabra, los signos gráficos y ortográficos, así como las construcciones simbólicas.

Es evidente que la Literatura es una expresión cultural de la colectividad socio-políticade la que emana, pero el Derecho también lo es. Uno de los más prestigiosos cultivadores de la Filosofía del Derecho, el ius-filósofo brasileño Miguel Reale, al distanciarse de la corriente neokantiana que concebía el Derecho como un fenómeno típicamente normativo, y al empezar a elaborar su Teoría tridimensional del Derecho, ponía ya de manifiesto que el Derecho hunde

La expresión fue usada por primera vez por PUCHTA en su obra Das Gewohnheitsrecht (1828), y que después hizo suya Savigny en su System des heutigen römischen Rechts (Sistema de Derecho Romano Actual) de 1840. Vid.: VON SAVIGNY, F., De la Vocación de nuestro siglo para la Legislación y la Ciencia del Derecho, Traducción del alemán de Adolfo G. Posada, Estudio preliminar sobre El Espíritu del Nuevo Derecho Alemán por el Doctor Enrique de Gandía, Editorial Heliasta, Buenos Aires, 1977. En el capítulo I, titulado "Origen del Derecho Positivo" al disertar sobre el origen del Derecho, o de otros aspectos propios de un pueblo como su lengua, sus costumbres y su constitución política, F. Von Savigny señala que: "Todas estas diferentes manifestaciones no tienen, en verdad, una existencia aparte, sino que son otras tantas fuerzas y actividades del pueblo, indisolublemente ligadas, y que sólo aparentemente se revelan a nuestra observación como elementos separados. Lo que forma un solo todo es la universal creencia del pueblo, el sentimiento uniforme de necesidades íntimas, que excluye toda idea de un origen meramente accidental y arbitrario." (p. 43) 
sus raíces en el mundo de la vida, subordinando así la experiencia jurídica a la experiencia social. Con ello, Miguel Reale se valía de la afortunada expresión de E. Husserl, Lebenswelt.

De esta manera, pasaba a considerar el Derecho como una realidad cultural, histórico-social, o experiencia histórico-cultural(Reale, 1997, pág. 89)producto de la libertad creadora del hombre. De la misma manera, con anterioridad, Eugen Ehrlich, tributario de una concepción positivista comteana y que podríamos situar dentro de la Escuela del Derecho Libre, cuestionaba la plenitud del ordenamiento jurídico, y defendía que el juez, en su función de intérprete del Derecho, debía considerar en sus resoluciones un Derecho vivo que no proviene del legislador sino de la dinámica social. Así, se valía E, Ehrlich del concepto Das Leben (Gómez García, 2005, pág. 11) tan fecundo en el ámbito doctrinal alemán del momento. Se trataba de ir más allá de la intención del legislador, para conocer el Derecho realmente vigente en la sociedad, pues el verdadero Derecho se halla fuera de las normas jurídicas, y es la sociedad misma la que lo crea (Gurvitch, 2001, págs. 118-119).Con semejante concepción sociológica de la norma jurídica, criticará E, Ehrlich la teoría clásica de las fuentes del Derecho. En efecto, como atinadamente se ha afirmado "una cosa es el Derecho como regla y otra bien distinta el Derecho como vida. Y la tragedia de la ciencia jurídica radica en que hasta ahora se ha circunscrito al primero, ignorando de antemano lo que es la efectividad del Derecho, aquello que en la sociedad es Derecho." (Elías de Tejada, 1977, pág. 634).

Con esta pretendida vinculación entre Derecho y Literatura se propicia una visión más abierta y menos dogmática del Derecho (Botero Bernal, A., y Narváez Hernández, J.R., 2010, pág. 6), ambos sectores de expresión humana se enriquecen mutuamente (Cantarella, 2007, pág. 10) ${ }^{2}$, bien

2 Vid. p. 10, donde podemos leer que: "Il método di indagine seguito dal primo filone consiste nell' analizzare se e come i testi letterari possano essere utilizzati dai giuristi per conoscere la realtà che li interessa; i cultori desde una consideración literaria del Derecho o bien desde una consideración jurídica de la Literatura, en donde ésta aparece como fuente para comprender la construcción del Derecho y los valores que lo inspiran (Botero Bernal, A., y Narváez Hernández, J.R., 2010, págs. 6-7).

En efecto, a pesar de que se ha puesto de manifiesto que "es difícil saber por qué dos dimensiones tan inconciliables como son la literatura y el derecho han sido a lo largo de los siglos impelidas a quererse por la mano de ilusorios eruditos" (Celemín Santos, 1996, pág. 9), se apunta en relación al objetivo último de esta pretendida unión o maridaje que "se verá satisfecho si sirve para que el hombre de leyes profundice en el mundo de las letras y para que, a su vez, el literato se acerque un poco más a los dominios del derecho. O dicho de otra forma: que le llegue al jurista la palabra sentida que sorprende, y se adentre el poeta en ese campo difícil de límites por el que caminar en libertad."(Celemín Santos, 1996, pág. 15)En efecto, quizás de una manera aún más gráfica se ha señalado que: "A lawyer without history or literature is a mechanic, a mere working Mason: if he possesses some knowledge of these, he may venture to call himself an architect."(Neville Turner, J. \& Williams, P., 1994, pág. XV).

\section{METODOLOGÍA}

Dada la riqueza que supone para el filósofo del Derecho estudiar lo jurídico poniéndolo en relación y contacto con las fuentes literarias que sean fiel reflejo de un determinado modelo de sociedad y de sus valores inherentes, hemos seleccionado un autor, un poeta y dramaturgo universal, como fue el granadino Federico García Lorca, miembro de la Generación del 27, para estudiar en su pensamiento aspectos

\footnotetext{
del secondo filone, invece, considerano il diritto come prodotto letterario, como narrazione, costruzione di storie, e si propongono di applicare le tecniche e i metodi della teoría e dell'analisi letteraria ai testi giuridici."
} 
claves, desde las perspectivas sociológica y filosófico- jurídica, como son las cuestiones relativas al tratamiento del género, la libertad y la justicia en su obra dramática.

Hemos leído con atención y detenimiento cada uno de sus dramas más representativos, todos ellos basados en hechos reales, para llegar a conocer el papel de la mujer, entender sus ansias de libertad y su concepto de lo justo. Percibimos que cada uno de estos conceptos destacados, en realidad, forman parte de una misma cadena vital, que conformaba entonces inescindiblemente el mundo femenino y su distinción radical con el rol social asumido tradicionalmente por el varón. Estos términos se convierten en atributos sucesivos el uno del otro, implicándose mutuamente, hasta llegar a la concepción de justicia subyacente en su obra, donde siempre parece contraponerse lo justo natural y lo justo legal, la ley natural y la ley social.

Para el estudio detenido de estas cuestiones hemos seleccionado los dramas lorquianos más sobresalientes de su producción teatral. Hemos acudido a las fuentes directas, y hemos mostrado aquellos textos concretos que mejor reflejan la intencionalidad del propio autor sobre los términos género, libertad y justicia. En todos ellos descubrimos la presencia de una mujer fuerte que se siente impelida a saltar por encima de los convencionalismos sociales, para alcanzar su propia concepción de lo justo, la mayor parte de las veces a consta de su propia vida.

\section{DERECHO Y LITERATURA: GÉNERO, LIBERTAD Y JUSTICIA EN LA OBRA DRAMÁTICA DE GARCÍA LORCA}

\subsection{La Generación del 27 y la obra de F. García Lorca. Su vinculación con el Krausismo jurídico español.}

Semejante interacción entre Derecho y Literatura se hace aún más palpable en determinados autores, quizás porque su grado de sensibilidad personal acoge más fácilmente el sentir humano cotidiano, sus aspiraciones, las exigencias sociales que le son inherentes y los condicionamientos históricos,políticos y morales de una época. Asimismo, existen momentos particularmente convulsos en la historia de la humanidad que impulsan a sus artistas y literatos a una peculiar y especialísima creatividad, no en vano a veces en momentos de aguda crisis emergen las más bellas creaciones artísticas.

Señalaba el jurista granadino Juan Osorio Morales (Osorio Morales, 1949) en un bello libro donde se ocupa magistralmente de poner de manifiesto la interacción existente entre Derecho y Literatura, que "en ocasiones, las obras literarias ofrecen al jurista algo más que datos aislados, aludidos incidentalmente en el curso de la narración... Pero hay otras obras, cuyo interés es aún mayor para el investigador del Derecho, porque en ellas el autor se plantea deliberadamente, como base de la trama, un problema jurídico, real o imaginario, en torno al cual se desarrolla la creación literaria.

Y estas permiten, no ya sólo conocer una posición personal, sino escrutar algo más importante: el ambiente jurídico de la época. Porque el literato al escribir se dirige siempre a sus contemporáneos. Sobre la mayor parte de las cuestiones en que fija su atención, siente con ligeras variantes, como ellos. Quizás al enfrentarse con algunos temas su personalidad señera y vigorosa, disiente. Pero tanto en un caso como en otro, vaya con la corriente o contra ella, refleja al escribir -por conformidad o por contraste- la sensibilidad de su tiempo." (Osorio Morales, 1949, págs. 10-11)

En este sentido, sería especialmente destacable como después de la primera guerra mundial, durante la década de 1920, surge una nueva generación de artistas, poetas y literatos, la denominada Generación del 27 (García López, 1983, pág. 685). Se trata de un grupo poético que se escalona desde Pedro Salinas, nacido en 1891, a Manuel Altolaguirre, nacido en 1905. Esta fecha de 1927 fue elegida por cumplirse el tricentenario de la muerte de Góngora (Gaos, 1977, pág. 13). Se produce una vuelta al elemento 
de popular, utilizándose el romance o la copla nacidos de las tradiciones y de la esencia más íntima del pueblo. Esta vuelta a lo popular va acompañada, además, de un retorno hacia lo humano, con lo cual tiene lugar lo que puede denominarse un neo-romanticismo orientado hacia la pasión y los sentimientos humanos más hondos. A ello, se añade la influencia fructífera de un movimiento revolucionario de origen francés, el superrealismo. Todos estos elementos, sabiamente conjugados, permitirán que la creación literaria alcance elevadas cotas de contenido dramático, dando como resultado, en definitiva, una poesía y un lirismo en la expresión profundamente renovados.

Inserto en la Generación del 27, encontramos al poeta y literato granadino Federico García Lorca (Guillén, 1991, págs. XXXI-XXXIV), cuyo trágico final le convertiría muy joven en víctima de la guerra civil española, siendo su brillante trayectoria literaria dramáticamente truncada en agosto del año 1936, cuando fue fusilado en la carretera de Víznar a Alfacar. Asesinado en los primeros días de la guerra civil española, el poeta de Fuente Vaqueros pronto se convertiría en leyenda viva, pues "pocos han sabido intuir tan profundamente como él la esencia del alma española, ni interpretar con tan emocionado fervor la voz y los mitos de la colectividad nacional a través de sus bellos poemas" (García López, 1983, pág. 689). Su vida y obra, así como el destino último de sus restos mortales, se han convertido en persistente objeto de interés científico (Roncagliolo, 2012) ${ }^{3}$.

3 El cadáver del poeta García Lorca nunca se ha encontrado, y ello se ha calificado como "uno de los grandes misterios de la Guerra Civil". En la introducción de esta obra se describe una extraña ceremonia celebrada en homenaje al poeta granadino, que tuvo lugar en diciembre de 1953 en la ciudad de Salto, a orillas del río que separa Uruguay de Argentina. Allí se le rindieron honores militares "como si se tratase de un funeral de Estado". En el acto, una lápida de 3X2 m con un poema inscrito, y unos albañiles que abrieron una fosa detrás de la lápida y enterraron en ella una caja blanca de las proporciones de un osario de cementerio. En aquel acto lleno de simbolismo se pronunciaron unas enigmáticas palabras: "Pueblo salteño que hiciste posible sin una sola voz adversa este silencioso y sencillo acto justiciero, gracias. Gracias por lo
En efecto, en su obra dramática hallamos una magistral mezcla de lo popular y lo aristocrático, un poderoso uso de la metáfora rebosante de valor simbólico, una destreza absoluta en el uso del lenguaje, en donde los diálogos pasan con enorme soltura de la prosa al verso y a su vez a la canción popular y, sobretodo encontramos un profundo conocimiento del alma humana, así como una excepcional muestra de la hondura trágica del sentimiento del pueblo andaluz.

La vida de García Lorca se enmarca dentro de dos acontecimientos de indudable trascendencia en la historia de España. Nace en 1898, año en el que tiene lugar el desastre colonial, la pérdida de las últimas colonias españolas en ultramar, y fallece en el verano de 1936, momento del estallido de la cruenta Guerra Civil española, una confrontación bélica entre hermanos.

En España, rebrota la desolación en el año 1898 con ocasión de la pérdida de las últimas colonias españolas (las islas de Cuba, Puerto Rico y el archipiélago de las Filipinas), sellándose con el Tratado de París de 10 de diciembre de 1898 la pérdida de las Antillas españolas. Ese sentimiento de desamparo encontraría consuelo en los intelectuales de la Generación del 98. El mundo de las letras sería refugio frente a la desazón. Ello da lugar a que se evolucione desde una actitud europeísta hacia una clara iniciativa que lleva a literatos y filósofos a rescatar los valores tradicionales y a centrar sus preocupaciones fundamentales en la realidad social española. No obstante, el granadino Ángel Ganivet nos brindaría ya en 1896, desde la recreación estética de su ciudad nataly desde su espíritu profundamente tradicionalista, la esperanza en la renovación, en la regeneración de España, al proclamar sabiamente, remedando al insigne San Agustín, que "in interiore Hispaniae hábitat veritas" (Ganivet, 1943, pág. 240 y ss.).

En 1936 se produce un recrudecimiento del clima político en España. El 18 de febrero las

que intuyes, por lo que adivinas y por lo que sostienes en el ámbito de mi patria..." (p. 14). 
elecciones dan el triunfo a las izquierdas, y el Frente Popular obtiene el poder. La politización de los intelectuales es casi total, inclinados a la izquierda, posicionándose desde el republicanismo radical al marxismo (Cano, 1962, pág. 117). Se ha apuntado que García Lorca apoyaba al Frente Popular, al igual que su propia familia (Gibson, 1986, págs. 28-29). En efecto, se ha afirmado que "a raíz de su fusilamiento, la figura de Lorca forma parte de toda la serie de símbolos utilizados para fortalecer la poesía política, que juega un papel fundamental en la defensa de la libertad popular y en la crítica del sistema político que la derecha española estaba intentando imponer." (García Montero, 1984, pág. 38)

El poeta pondría su entera personalidad al cultivo de la creación artística poética y dramática, siendo su obra permeable a las influencias históricas, políticas y sociales externas. Su carácter abierto y liberal le haría alcanzar un magnetismo especial. Se ha escrito que "a los pocos minutos de empezar a hablar Federico, ya todos, hombres, mujeres y hasta si me apuras los pájaros, se quedaban prendidos de su encanto y gracia,... El aire semejaba detenerse alrededor de él, y el tiempo y todo parecía aquietado, salvo sus manos y sus labios, que volaban como mariposas morenas o pétalos de flores; salvo sus palabras, que nos enamoraban a todos, sin distinción, y nos dejaban presos". (Reina, 2012, pág. 90).

$\mathrm{Su}$ trayectoria intelectual nos lleva a destacar su licenciatura en Derecho, que culmina en 1923, y en Filosofía y Letras en la Universidades de Granada y en la Central de Madrid, y su vinculación con el notable centro cultural que fue la Residencia de Estudiantes (Cano, 1962, pág. 36 y 39), fundada en 1910, que se hallaba en los altos del Hipódromo, al final de la Castellana, detrás del Museo de Historia Natural, en cuyo ambiente británico -un Oxford madrileño- el poeta granadino pasaría nueve años intensos de su formación como literato.

Era la Residencia de Estudiantes, "a la manera de un college oxfordiano en las afueras de Madrid, un lugar de convivencia de profesores, estudiantes y artistas, que irradiaron su actividad en diversos campos de la cultura española" (Gil Cremades, 1999, págs. 48-49). Allí, García Lorca entraría en contacto con la corriente cultural denominada Krausismo español (Lorca Navarrete, J.F., y Lorca Martín de Villodres, Mª I.,, 2002, $2^{\text {a }}$ edic., págs. 201-250), que pretendía un renacimiento ético (G. De Valdeavellano, 1981, págs. 11-13y 20), y una renovación intelectual de la España de finales del siglo XIX y comienzos del XX, y que encontraba su origen en el pensamiento del filósofo alemán F. Krause, conocido por una minoría de españoles exiliados en Francia en uno de los vaivenes en la pugna entre absolutistas y liberales, que asistieron a los cursos de Derecho Natural que Henri Ahrens impartió en la Sorbona entre 1830 y 1833 (Gil Cremades, 1999, pág. 31).

El pensamiento de F. Krause sería, por tanto, conocido en nuestro país, pues sus obras fueron, asimismo, difundidas por Julián Sanz del Río (Sanz del Río, 1857). La filosofía krausista, que transmitía una doctrina socialista, liberal y laica con tendencia europeísta, estaba dirigida hacia la conquista de lo que Adolfo Posada definió como el hombre interior (Lorca Navarrete J., 1971, pág. 29), que es aquel que actúa movido por exigencias, impulsos e ideales éticos, altruistas, solidarios y humanos (Lorca Navarrete J. , 1973, núm. 15). No en vano, el Krausismo español ha sido definido como un "movimiento que plasmó en una corriente de pensamiento idealista, de gran contenido ético y con un carácter eminentemente práctico." (Lorca Navarrete J., "La Filosofía Jurídica Española Contemporánea", 1996, pág. 297)

Allí a la Residencia de Estudiantes, llega García Lorca en la primavera de 1919 para estudiar por consejo de Fernando De Los Ríos, que era fiel amigo de su familia (Cano, 1962, pág. 36). Federico García Lorca conoce por primera vez a Fernando De Los Ríos cuando ingresa en la Universidad de Granada en el año 1915, donde el rondeño alcanzaría la cátedra de Derecho Político en 1911. Allí en las aulas universitarias, surge entre ambos una sólida amistad. 
Fernando De Los Ríos, quien era discípulo de Francisco Giner de los Ríos, eminente catedrático de Filosofía del Derecho, en torno a cuyo magisterio se crearía la Institución Libre de Enseñanza, alcanzó gran actividad política durante la II República española, llegando a ser Ministro de Justicia y de Instrucción Pública y Estado. Fernando De Los Ríos, tras licenciarse y doctorarse en Derecho, marcharía a Alemania donde completó su formación jurídica, recibiendo la benéfica influencia del neokantismo de la Escuela de Marburgo, que unida a la influencia krausista ya recibida de Francisco Giner, daría lugar a que su pensamiento fuera calificado de socialismo humanista o neokantiano (De Los Ríos Urruti, 1997, pág. 294), el cual era fruto de un sincretismo que cohonestaba la raíz krausista con un socialismo no marxista (Rodríguez de Lecea, 1997, pág. XVII) (Gil Cremades, 1999, pág. 55).

Años más tarde, en 1932, cuando Fernando de los Ríos era ministro de Instrucción Pública del gobierno de Azaña, fue quien nombró a Federico García Lorca director del nuevo teatro universitario "La Barraca"; el objetivo era llevar el teatro clásico español a todos los pueblos de España (Gibson, 1986, pág. 17). Los grandes dramaturgos del Siglo de Oro español se darían a conocer gracias a este grupo de teatro universitario que recorrería incansablemente la geografía española.

La estrecha vinculación y sintonía ideológica entre Federico García Lorca y Fernando De Los Ríos se evidencia en algún poema que con cierto gracejo dedica al rondeño ("Ay, don Fernando de los Ríos, / barbas de santo, / padre del socialismo/ de guante blanco. / Ay, don Fernando de los Ríos, /barbas de santo, / Besteiro es elegante, pero no tanto.”)(García Lorca, 1991, pág. 1059).

\subsection{La obra dramática de F. García Lorca}

En las obras de García Lorca encontramos personajes de gran fuerza narrativa y de gran trascendencia ética, que invitan a un análisis sereno y crítico. Particularmente, interesantes resultan los personajes femeninos de su obra dramática, auténticas protagonistas y heroínas de lo socialmente cotidiano, ansiosas de libertad y justicia. La mujer aparece descrita por las notas de la valentía, la fuerza y, sobre todo, marcadas por la obediencia a un código ético y a un sentido de justicia superior. La mujer lorquiana nos recuerda a la joven Antígona del dramaturgo griego Sófocles, que valerosamente decide desobedecer la ley positiva del tirano Creonte, para dar justa sepultura al cadáver de su hermano Polinice muerto en Tebas.

Antígona decide obedecer a unas leyes no escritas (ágrapta nómina) que no son de hoy ni de ayer, sino de siempre, que nadie sabe cuándo surgieron, que nacen de la voluntad de los dioses y que son indicadoras de una justicia natural superior orientadora de nuestra conducta, y que el hombre descubre a la luz de su propia conciencia (Sófocles, 1995). En Antígona se simboliza el contraste entre una legislación natural, superior y eterna, y una legislación humana (ley positiva) que es fruto del arbitrio de un tirano (Tomain, 2009). Se plasma, así, en la joven Antígona el símbolo de la desobediencia a una ley positiva injusta, de quien reconoce como únicamente válidas unas normas no escritas e inquebrantables, anteriores a toda ley humana positiva (Antígona, 440-470).

Los dramas lorquianos aparecen basados en hechos y sucesos reales, en donde la mujer es víctima de las convenciones sociales. Lorca refleja en sus obras la realidad psicológica de la mujer española de su tiempo, profundamente marcada por elementos tales como la salvaguarda del honor y la honra, la pasión amorosa y la sexualidad, el deseo de maternidad, y la concepción de moral social vigente que trata de frenar en ella toda ansia por alcanzar su libertad e independencia;con lo cual, nos describe una mujer, siempre sometida al universo masculino, frente al que trata de rebelarse.

\subsubsection{Mariana Pineda (1925)}

Con la obra Mariana Pineda (1925) (García Lorca F. , Mariana Pineda, 1984), un drama de época situado en la convulsa España decimonónica determinada por la lucha entre liberales y 
realistas durante la restauración monárquica del rey Fernando VII, inicia Federico García Lorca su producción teatral. Mariana, hija de un capitán de navío, Caballero de Calatrava, yviuda con dos hijos, que ama profundamente al capitán D. Pedro de Sotomayor, representa una heroína (García Lorca, "Mariana Pineda en Granada", 1991, págs. 413-415) liberal de la España del siglo XIX.

En este personaje femenino se exalta la pasión amorosa y la libertad. Mariana Pineda será ajusticiada el 26 de mayo de 1831, acusada de bordar la bandera de la libertad, en tafetán morado y letras verdes, y su ejecución será precisamente símbolo de la lucha contra el absolutismo. Mariana decide no delatar a sus camaradas liberales, no denunciar a los conjurados, y sacrificar así su propia vida antes que vivirla indignamente. Ella espera que la salve su amante, quien, sin embargo, la abandona cobardemente huyendo a Inglaterra, a la vez que la sociedad granadina la deja en el olvido el día de su cruel ejecución. Sin embargo, el transcurso del tiempo, y la llegada del Estado de Derecho constitucional, le haría justo recuerdo a su memoria.

En el año 2006, la Unión Europea rindió homenaje y le otorgó su nombre a la entrada principal del Parlamento europeo (Estrasburgo), como símbolo de la aportación española en la lucha por los derechos y libertades en Europa. Allí mismo, en la entrada protocolaria, se ha ubicado una estatua, un busto, de esta granadina universal en su recuerdo.

El personaje de Mariana aparece dibujado de forma clara en contraste con el rol tradicionalmente masculino. Así, Doña Angustias, su madre adoptiva, no entiende por qué su hija ha de ocuparse de cuestiones políticas que son propias de hombres: "Se le ha puesto la sonrisa casi blanca, / como vieja flor abierta en un encaje. / Ella debe dejar esas intrigas. / ¿Qué le importan las cosas de la calle? / Y si borda, que borde unos vestidos/ para su niña, cuando sea grande. / Que si el rey no es buen rey, que no lo sea; / las mujeres no deben preocuparse." (Estampa primera, Escena I, pp. 14-15).
La imagen de la mujer ociosa y despreocupada de cuestiones de alguna relevancia o trascendencia es representada a la perfección por las hijas del Oidor de la Chancillería de Granada, Amparo y Lucía. Mientras tanto, a lo largo de las sucesivas escenas, el personaje de Mariana Pineda va cobrando fuerza e intensidad dramática, pues presiente su propia muerte: "Tengo, sin embargo, / que estar muy serena, muy serena; aunque me siento vestida de temblor y llanto." (Estampa primera, Escena VI, pp. 39).

La fatalidad y el destino se cierneninevitablemente sobre Mariana, quien en todo momento se alza en símbolo de la libertad, incluso llega aayudar a su amante a escapar, arriesgando su propia vida: "Él ama la libertad/ y yo la quiero más que él." (Estampa primera, Escena VII, p. 46). Su mismo amante, Pedro de Sotomayor, lo reconoce: "En el mayor sigilo conspiramos. iNo temas! / La bandera que bordas temblará por las calles/ entre el calor entero del pueblo de Granada. / Por ti la Libertad suspirada por todos/ pisará tierra dura con anchos pies de plata." (Estampa segunda, Escena V, p. 64). O más adelante, su amante, reconociéndole su valentía, también le dice: "iMariana, la bandera que bordaste/ será acatada por el rey Fernando, / mal que le pese a Calomarde!" (Estampa segunda, Escena VII, p. 75). Aquí se contrapone el ideal de libertad frente al poder del Estado. Se menciona, concretamente, a Francisco Tadeo Calomarde, quien ocupó el ministerio de Gracia y Justicia durante la restauración absolutista de Fernando VII.

Pero la fortaleza de Mariana supera una fuerte tentación. Ramón Pedrosa y Andrade, como autoridad representante de la Administración -comisionado especial para las causas de conspiración contra la seguridad del Estado-,la visita con la intención de que confiese los nombres de los conjurados y así, a cambio,podría salvar su vida.Además, Pedrosa le propone al mismo tiempo que acepte su amor que siempre ha rechazado: "Sé también/ que hay mucha gente complicada. / Espero que dirás sus nombres, ¿verdad?/ Nadie sabrá lo que ha pasado. Yo te 
quiero/ mía, ċlo estás oyendo? Mía o muerta. / Me has despreciado siempre; pero ahora/ puedo apretar tu cuello con mis manos, / este cuello de nardo transparente, / y me querrás porque te doy la vida." (Estampa segunda, Escena IX, p. 94). Mariana con toda dignidad y fortaleza le replica: "iEso nunca! iPrimero doy mi sangre! / Que me cueste dolor, pero con honra. / iSalga de aquí!" (Estampa segunda, Escena IX, p. 94). Es más, Mariana responde: "iQué me importa! / Yo bordé la bandera con mis manos; / con estas manos, imírelas, Pedrosa!, / y conozco muy grandes caballeros/ que izarla pretendían en Granada. / iMás no diré sus nombres!" (Estampa segunda, Escena IX, p. 95).

Mariana se hospeda como prisionera en el Convento de Santa María Egipcíaca de Granada (Martín Recuerda, 1991), que hace la función de cárcel, a la espera de su triste e inevitable final, mientras las novicias la observan y contemplan su serenidad ante la condena a muerte con asombro: "iQué mujer tan valiente! Cuando ayer/ vinieron a leerle la sentencia/ de muerte, no ocultó/ su sonrisa." (Estampa tercera, Escena I, p. 99). Mariana, mujer que supera en valentía y fortaleza a todos los personajes masculinos de esta obra lorquiana, decide morir por la defensa de la Libertad y entregar su vida por lo que considera lo justo.

En efecto, se produce en la obra un claro contraste entre lo que la ley humana positiva entiende por Justicia, y lo que Mariana y otros personajes guiados por un sentido natural de lo justo conciben como tal. En la Estampa tercera, Escena I, hay una conversación entre dos novicias del convento, donde se encuentra presa Mariana a la espera de su final, que comentan entre sí, y que refleja precisamente ese contraste entre lo justo natural y lo justo legal: Novicia 1a: "En la iglesia/ la vi después llorando/ y me pareció que ella/ tenía el corazón en la garganta. / ¿Qué es lo que ha hecho?"; Novicia $2^{\text {a. }}$ "Bordó una bandera"; Novicia 1ª: "¿Bordar es malo?”; Novicia 2a: "Dicen que es masona"; Novicia 1"a: "¿Qué es eso?"; Novicia 2a. "Pues... ino sé!"; Novicia $1^{\mathrm{a}}$ : “¿Por qué está presa?”; Novicia 2a. "Porque no quiere al rey"; Novicia $1^{\text {a: }}$ "¿Qué más da? ¿Se habrá visto?”; Novicia $2^{\mathrm{a}}$ : "iNi a la reina!";

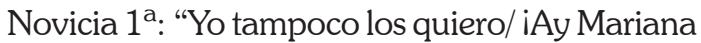
Pineda! / Ya están abriendo las flores/ que irán contigo muerta." (Estampa tercera, Escena I, pp. 99-100). Más tarde, Pedrosa visita a Mariana en el convento, y ésta clama Justicia: "iNo puede ser! iCobardes! ¿Y quién manda/ dentro de España tales villanías? / ¿Qué crimen cometí? ¿Por qué me matan? / ¿Dónde está la razón de la Justicia? / En la bandera de la Libertad/ bordé el amor más grande de mi vida. / ¿Y he de permanecer aquí encerrada? / iQuién tuviera unas alas cristalinas/ para salir volando en busca tuya!" (Estampa tercera, Escena V, p. 114). La propia Madre Carmen, monja del convento, exclama: "Señor, no es justo..." (Estampa tercera, Escena V, p. 115), y una novicia afirma: "iQué injusticia! Esta mujer/ de seguro fue engañada." (Estampa tercera, Escena VII, p. 119).

Mariana en su defensa de la Libertad, que asimila a la Justicia, se identifica ella con la Libertad misma: "iPues yo seré la misma Libertad que tu adoras!" (Estampa tercera, Escena VIII, p. 123). Mariana decide entregarse por defender la Libertad, que ella vincula con la Justicia: "iMorir! iQué largo sueño sin ensueños ni sombras! / Pedro, quiero morir por lo que tú no mueres, / por el puro ideal que iluminó tus ojos: / iLibertad! Porque nunca se apague tu alta lumbre/me ofrezco toda entera. iArriba, corazón! / iPedro, mira tu amor a lo que me ha llevado! / Me querrás, muerta, tanto, que no podrás vivir." (Estampa tercera, Escena VIII, p. 125).

En la Escena última del drama, se intensifica aún más esa idea, Mariana se identifica plenamente con la Libertad misma, siendo Libertad y Justicia el mismo concepto: "(...) pero yo soy la misma Libertad. Doy mi sangre, / que es tu sangre y la sangre de todas las criaturas. / iNo se podrá comprar el corazón de nadie! / Ahora sé lo que dicen el ruiseñor y el árbol. / El hombre es un cautivo y no puede librarse. / iLibertad de lo alto! Libertad verdadera, / enciende para mí tus estrellas distantes". (Estampa tercera, Escena última, p. 128). Las últimas palabras de Mariana 
Pineda se dirigen en el mismo sentido: "iYo soy la Libertad porque el amor lo quiso! / iPedro! La Libertad, por la cual me dejaste. / iYo soy la Libertad, herida por los hombres! / iAmor, amor, amor, y eternas soledades!" (Estampa tercera, Escena última, pp. 129-130).

\subsubsection{Bodas de Sangre (1933)}

Federico García Lorca continúa su producción teatral con tres grandes dramas ubicados en el ámbito rural y campesino. Nos referimos a Bodas de Sangre (1933), Yerma (1934) y La Casa de Bernarda Alba (1936). En los tres aparece de nuevo como personaje protagonista una mujer de fuerte carácter y personalidad, que se enfrenta con crudeza a su realidad cotidiana. Los temas de la honra, la pasión amorosa y sexualidad, y los convencionalismos sociales marcan el ritmo del hilo argumental. Además, el factor del destino -el fatalismo- planea inevitablemente de principio a fin en la trama de estas obras, anunciando siempre el fatídico desenlace.

En el mes de marzo del año 1933, García Lorca estrena en Madrid Bodas de Sangre (García Lorca F., 1986). Será un gran éxito. Posteriormente, estrena dicho drama en Buenos Aires, en donde de nuevo obtiene un rotundo triunfo. En esta obra lorquiana, una vez más, encontramos un personaje femenino de gran fuerza que sobresale por encima de las demás de su mismo género. Se trata del personaje de la Madre del Novio. Mujer viuda, a quien ya le ha fallecido un hijo, y que sólo cuenta con su otro vástago (el Novio). Las muertes que han cercenado su vida han estado marcadas por reyertas producidas mediante cuchillos o navajas en el ambiente rural de su pueblo.

Es por ello, que el simbolismo, obsesivamente presente en la obra lorquiana, hace que la muerte se identifique con esta arma blanca. La Madre es, por ello, desconfiada, temerosa de la joven vida de su ya único hijo, pero a la vez posee enorme fuerza. Se ha afirmado que La Madre "representa la fidelidad de la tierra. Es fuerte y constante, paciente ante la adversidad. Vive en comunión con sus muertos, ligada a ellos a través del recuerdo y de la llama incombustible del odio hacia la casta enemiga. Se vuelca en ternura con su hijo, pero las leyes sociales del pundonor la impulsan a entregarlo también a la muerte". (Rodríguez, 1986, pp. 141-142).

La Madre tiene un concepto tradicional y sumamente anquilosado del rol que socialmente ha de desempeñar una mujer y de lo que ha de ser una buena esposa. Por ello, cada mañana cuando su hijo marcha al campo a trabajar, teme por su vida, y desea que hubiese sido en lugar de varón, una mujer: "Que me gustaría que fueras una mujer. No te irías al arroyo ahora y bordaríamos las dos cenefas y perritos de lana" (Acto primero, Cuadro primero, líneas 55-57, p. 39). Cuando su hijo le anuncia sus planes de boda, muestra su recelo. No obstante, de su futura nuera destaca su dedicación a las tareas domésticas: "... Yo sé que la muchacha es buena. ¿Verdad que sî́? Modosa. Trabajadora. Amasa su pan y cose sus faldas, y siento, sin embargo, cuando la nombro, como si me dieran una pedrada en la frente" (Acto primero, Cuadro primero, líneas 75-80, p. 42).

Además, abunda en sus consideraciones sobre la futura esposa de su hijo, aludiendo a un aspecto crucial, la fidelidad: "Sí. Yo no miré a nadie. Miré a tu padre, y cuando lo mataron miré a la pared de enfrente. Una mujer con un hombre, y ya está" (Acto primero, Cuadro primero, líneas 101-104, p. 43). Es una fidelidad que va desde el noviazgo hasta después del fallecimiento del cónyuge, es ya de por vida. El tema de la honra femenina está omnipresente en todos los pasajes de la obra, condicionando su hilo argumental. Cuando su hijo le plantea la posibilidad de darle nietos en el futuro, ella entusiasmada con la idea, responde mostrando nuevamente su concepto de lo que significa la condición femenina: "Sí, pero que haya niñas. Que yo quiero bordar y hacer encaje y estar tranquila". (Acto primero, Cuadro primero, líneas $124-125$, p. 44). E incluso, en una conversación posterior situada en Cuadro segundo del Acto segundo, la Madre le dice al Padre de la Novia sobre el tema de los nietos futuros que la pareja pueda darles: "iY alguna hija! iLos varones son del viento! Tienen por 
fuerza que manejar armas. Las niñas no salen jamás a la calle" (líneas 1134-1136, p. 86).

La Madre, preocupada por la honestidad de la futura mujer de su hijo, consulta a una vecina, quien le responde: "... es buena. Acostumbrada a la soledad". (Acto primero, Cuadro primero, líneas 171-174, p. 45). Con estas palabras se subraya aún más el concepto de mujer que era valorado en el ambiente rural de la época en que vivió García Lorca. Se trataba de una mujer que había de ocuparse del hogar, del marido e hijos, en casa siempre, guardando fidelidad absoluta hasta después de la muerte del cónyuge, y renunciando a toda diversión que no fueran aquellas consentidas por la costumbre o la convención social.

Es la imagen de una mujer abnegada, reducida a un segundo plano, resignada ante el destino que le había tocado vivir. Precisamente, este prototipo es representado por la mujer de Leonardo, prima de la futura esposa del Novio, y ello puede apreciarse en sus propias palabras: "No sé lo que pasa. Pero pienso y no quiero pensar. Una cosa sé. Yo ya estoy despachada. Pero tengo un hijo. Y otro que viene. Vamos andando. El mismo sino tuvo mi madre. Pero de aquí no me muevo" (Acto segundo, Cuadro primero, líneas 1030-1034, p. 83).

En el pueblo, se comenta que Leonardo tuvo hace algunos años un noviazgo con la mujer que ahora va a contraer matrimonio con el personaje del Novio. El hecho de que sea Leonardo el único personaje que en esta obra cuente con nombre propio, propicia de forma determinante que toda la trama gire alrededor de él, subrayando el notable protagonismo de este personaje masculino que hará desencadenarse toda la tragedia. En efecto, el fatal desenlace se anuncia casi desde el comienzo de la obra, haciéndose patente en la nana que la propia suegra de Leonardo canta a su nieto, en cuyos versos puede observarse que el dramatismo de la obra se intensifica: "Duérmete rosal, / que el caballo se pone a llorar. / Las patas heridas, las crines heladas, dentro de los ojos/ un puñal de plata. / Bajaban al río. / iAy, cómo bajaban! / La sangre corría/ más fuerte que el agua" (Acto primero, Cuadro segundo, líneas 243-252, pp. 48-49).

El pasado amor entre Leonardo y la Novia-futura esposa del Novio- estuvo truncado por intereses económicos. Leonardo apenas poseía fortuna a diferencia del personaje de la Novia. Ahora, en cambio, al concertarse su boda con el Novio, se unen dos importantes patrimonios. Tal como afirma el personaje de la Suegra: "Se van a juntar dos buenos capitales" (Acto primero, Cuadro segundo, línea 377, p. 54). O como ratifica el Padre de la Novia en estas significativas palabras: "Lo mío es de ella y lo tuyo de él. Por eso. Para verlo todo junto, iqué junto es una hermosura!" (Acto primero, Cuadro tercero, líneas 485-487, p. 61).

García Lorca no quiere dejar pasar la oportunidad de poner de manifiesto que, en la sociedad de la época, los intereses económicos eran el factor determinante a la hora de concertar las uniones matrimoniales, quedando muy por encima de los propios sentimientos de los desposados. Es más, el autor deja claro como los matrimonios eran acordados por los propios padres, sin que los hijos, sobre todo las hijas, tuvieran algo que decir u objetar. Así, en la petición de mano, la Madre del Novio dirá orgullosa: "Mi hijo es hermoso. No ha conocido mujer. La honra más limpia que una sábana puesta al sol" (Acto primero, Cuadro tercero, líneas 504-506, p. 61).

Ante lo que el Padre de la Novia le replica: "Qué te digo de la mía. Hace las migas a las tres, cuando el lucero. No habla nunca; suave como la lana, borda toda clase de bordados y puede cortar una maroma con los dientes." (Acto primero, Cuadro tercero, líneas 507-511, pp. 61-62). De nuevo, se pone de manifiesto el concepto de mujer estimado válido y adecuado según los cánones sociales en el ambiente rural de la época. Dedicada a las tareas del hogar, en silencio y fuerte, tanto como para "cortar una maroma con los dientes", así define a la Novia su propio padre.

Es significativo que el autor abunde de forma tan reiterada, como si de una crítica y una denuncia 
social se tratase, en la cuestión del género, en el concepto de mujer aceptado en su época. Creemos que la explicación de ello, en este caso, es contrastar radicalmente esta concepción femenina de mujer abnegada y sumisa con el personaje principal de la Novia que, entendemos, representa además de la valentía y la fortaleza, la libertad misma (no en vano, ella se compara con un hombre cuando su Criada le dice "tienes más fuerza que un hombre"- línea 600-, declarando: "¿No he hecho yo trabajos de hombre? iOjalá fuera!" (Acto primero, Cuadro tercero, líneas 601-602, p. 65)). Pues, el personaje de la Novia, sin importarle los convencionalismos sociales, decidirá saltarse todas las barreras y huir tras la celebración de su boda, a caballo con su antiguo amor, Leonardo. Aquí el amor se sobrepone a los intereses económicos. Decide saltarse su propio destino, desligarse del fatalismo, del sino para el que estaba predestinada. Decide romper un matrimonio concertado por intereses donde no existe el amor.

Temas como la pasión, honra de la mujer y su virginidadson ingredientes esenciales que van haciendopresagiar el trágico final, en el que la ya desposada provoca a su suegra a que contraste su virginidad, produciéndose una identificación entre un primitivo sentido de justicia y la venganza: "iCalla, calla! Véngate de mí, iaquí estoy! Mira que mi cuello es blando; te costará menos trabajo que segar una dalia de tu huerto. Pero ieso no! Honrada, honrada como una niña recién nacida. Y fuerte para demostrártelo. Enciende la lumbre. Vamos a meter las manos; tú, por tu hijo; yo, por mi cuerpo. Las retirarás antes tú". (Acto tercero, Cuadro último, líneas 2097-2104, p. 128).

El contraste entre el rol masculino y femenino en la sociedad rural de la época de García Lorca queda plasmado definitivamente en las palabras que la Madre, a modo de consejo, dedica a su hijo, el Novio, tras el enlace, para que consiga dominar a su mujer durante la convivencia marital: "Con tu mujer procura estar cariñoso, y si la notas infatuada o arisca, hazle una caricia que le produzca un poco de daño, un abrazo fuerte, un mordisco y luego un beso suave. Que ella no pueda disgustarse, pero que sienta que tú eres el macho, el amo, el que manda. Así aprendí de tu padre. Y como no lo tienes, tengo que ser yo la que te enseñe estas fortalezas" (Acto segundo, Cuadro segundo, líneas 1362-1370, pp. 96-97). En efecto, la Madre subraya "tú eres el macho, el amo, el que manda", creemos que en estas palabras se resume el concepto de hombre-esposo de la época, y que el autor recoge con absoluta rotundidad.

En el drama Bodas de Sangre toda esta argumentación entorno a la disyuntiva entre Género femenino-masculino yLibertad, lleva en esta obra lorquiana, una vez más, al planteamiento de la Justicia. De nuevo, dos sentidos de Justicia se contraponen. Uno, aquello que es asumido como justo por la conciencia popular, que en esta ocasión se identifica con un sentido primitivo de venganza, y lo que sería la justicia según la ley. Así, la Madre cuando descubre la huida de su nuera con su amante Leonardo, increpa al Padre de aquella, añadiendo: "...Dos bandos. Aquí hay ya dos bandos. Mi familia y la tuya. Salid todos de aquí. Limpiarse el polvo de los zapatos. Vamos a ayudar a mi hijo. Porque tiene gente; que son sus primos del mar y todos los que llegan de tierra adentro. iFuera de aquí! Por todos los caminos. Ha llegado otra vez la hora de la sangre. Dos bandos. Tú con el tuyo y yo con el mío. iAtrás! iAtrás!" (Acto segundo, Cuadro segundo, líneas 1417-1427, pp. 98-99).

Incluso, ya el personaje del Leñador $1^{\circ}$, ante la huida de los enamorados, sentencia: "Hay que seguir el camino de la sangre" (Acto tercero, Cuadro primero, líneas 1447-1448, p. 102). Añadiendo, seguidamente que: "¿Y qué? Vale más ser muerto desangrado que vivo con ella podrida" (Acto tercero, Cuadro primero, líneas 14511452 , p. 102). Todo el fatalismo, que envuelve al argumento de este drama de comienzo a fin, termina con la muerte de los dos jóvenes, el Novio y Leonardo, y un personaje llamado Mendiga sentencia finalmente: "Los dos cayeron, y la novia vuelve/ teñida en sangre falda y cabellera. / Cubiertos con dos mantas ellos vienen/ sobre los hombros de los mozos altos. / Así fue; nada más. 
Era lo justo. /Sobre la flor del oro, sucia arena" (Acto tercero, Cuadro último, líneas 1985-1990, p. 124). La Mendiga dice sin más "era lo justo", y ello refleja el sentido de lo justo del pueblo que está determinado por fuertes tradiciones y férreos convencionalismos, equidistante del sentido de lo justo albergado por la ley.

\subsubsection{Yerma (1934)}

García Lorca escribe Yerma (García Lorca F. , Yerma. Poema trágico en tres actos y seis cuadros, 1983), con la intención de narrar una tragedia sobre la mujer estéril. Como se ha apuntado, certeramente, en realidad Lorca no pretendió exponer un argumento concreto, sino desarrollar un carácter femenino a lo largo de la obra (Gil, 1983, pág. 27). Se estrenó en diciembre de 1934 en el Teatro Español, de Madrid, con gran éxito.

Yerma lleva casada con Juan, ganadero y labrador,veinticuatro meses, y aún no ha concebido un hijo. Ello le provoca una gran ansiedad y pesadumbre, que no es compartida por su esposo. El matrimonio fue concertadopor el padre de Yerma, y ella lo aceptó felizmente ante la expectativa de ver cumplido su deseo de maternidad: "Mi marido es otra cosa. Me lo dio mi padre y yo lo acepté. Con alegría. Esta es la pura verdad. Pues el primer día que me puse novia con él ya pensé... en los hijos...Y me miraba en sus ojos. Sí, pero era para verme muy chica, muy manejable, como si yo misma fuera hija mía" (Acto primero, Cuadro segundo, p. 56).

El tema de los matrimonios acordados por los padres en función de intereses económicos se vuelve a poner de manifiesto en este drama lorquiano, al igual que sucediera en Bodas de Sangre como ya tuvimos ocasión de poner de manifiesto más arriba. Ahora, Yerma, tras dos años, $y$ al no haber sido madre, piensa que es la falta de amorhacia su esposo la causa de su infertilidad, y empieza a pensar que si hubiera contraído matrimonio con el pastor Víctor, quizás sí hubiera sido madre ("Quizá por eso no hayas parido a tiempo. Los hombres tienen que gustar, muchacha. Han de deshacernos las trenzas y darnos de beber agua en su misma boca. Así corre el mundo", Acto primero, Cuadro segundo, p. 56).

De nuevo, se halla obsesivamente presente el tema de la honra femenina que condiciona radicalmente la vida de Yerma, pues le impide, absolutamente, siquiera pensar en intentar concebir un hijo fuera de su matrimonio: "Se lo reconozco en la mirada, y como no los ansía no me los da. No lo quiero, no lo quiero y, sin embargo, es mi única salvación. Por honra y por casta. Mi única salvación" (Acto tercero, Cuadro primero, p. 93). Ello se pone de manifiesto cuando busca consejo en el personaje sabio y experimentado de la Vieja, la cual le dice: "iAy, qué flor abierta! Qué criatura tan hermosa eres. Déjame. No me hagas hablar más. No quiero hablarte más. Son asuntos de honra y yo no quemo la honra de nadie. Tú sabrás. De todos modos debías ser menos inocente" (Acto primero, Cuadro segundo, p. 57).

En la conversación que sostienen unas lavanderas en el Cuadro primero del Acto segundo, se muestra la importancia de la honra de la mujer casada en la mentalidad rural: "Yo planté un tomillo, / yo lo vi crecer. / El que quiera honra/ que se porte bien" (p. 66). La preocupación de la honra rebrota en el Cuadro segundo del Acto segundo, pues Juan ha encargado a sus dos hermanas solteras que cuiden de su esposa Yerma y la vigilen. Así, Juan se dirige a sus hermanas: "...Una de vosotras debía salir con ella, porque para eso estáis aquí comiendo en mi mantel y bebiendo mi vino. Mi vida está en el campo, pero mi honra está aquí. Y mi honra es también la vuestra" (p. 75). Asimismo, muy significativa en este mismo sentido es la afirmación que realiza Juan refiriéndose a Yerma: "Y que las familias tienen honra y la honra es una carga que se lleva entre dos" (Acto segundo, Cuadro segundo, p. 79).

Al mismo tiempo, Juan, marido de Yerma, no deja pasar ocasión para recordar a su esposa sus obligaciones domésticas: Juan: "...Ya sabes que no me gusta que salgas"/ Yerma: "Nunca salgo"/ Juan: "Estás mejor aquî"/ Yerma: "Sî"/ Juan: "La calle es para la gente desocupada"/Yerma: "Claro" 
(Acto primero, Cuadro primero, pp. 44-45).Yerma representa el prototipo de mujer casada, dentro de un ambiente rural que sólo vive para ocuparse del hogar y del marido, ajena por completo a otras facetas de realización personal ("Las muchachas que se crían en el campo como yo tienen cerradas todas las puertas" Acto primero, Cuadro segundo, p. 57, o más avanzado el hilo argumental, Yerma con dolor afirma: "...Vivo sumisa a ti, y lo que sufro lo guardo pegado a mis carnes" - Acto segundo, Cuadro segundo, p. 77).

El personaje de la Muchacha $2^{a}$ refleja claramente la frustrante vida de la mujer casada de la época: "Yo tengo diecinueve años y no me gusta guisar, ni lavar. Bueno, pues todo el día he de estar haciendo lo que no me gusta. ¿Y para qué? ¿Qué necesidad tiene mi marido de ser mi marido? Porque lo mismo hacíamos de novios que ahora... también tú me dirás loca, ila loca, la loca! Yo te puedo decir lo único que he aprendido en la vida: toda la gente está metida dentro de sus casas haciendo lo que no les gusta. Cuánto mejor se está en medio de la calle. Ya voy al arroyo, ya subo a tocar las campanas, ya me tomo un refresco de anís". (Acto primero, Cuadro segundo, p. 60).

En el Cuadro segundo del Acto segundo, Juan recuerda una vez más de forma tajante a Yerma sus obligaciones domésticas, y la conveniencia de que permanezca encerrada en casa: "¿Es que no conoces mi modo de ser? Las ovejas en el redil y las mujeres en su casa. Tú sales demasiado. ¿No me has oído decir esto siempre?” (p. 76), y después añade "No me gusta que la gente me señale. Por eso quiero ver cerrada esa puerta y cada persona en su casa" (pp. 79). En relación a ello, es muy concisa y expresiva la valoración que hace Yerma de su vida conyugal con Juan: "Mi marido me da pan y casa" (Acto segundo, Cuadro segundo, p. 83).

En consecuencia, Yerma siente una necesidad profunda de libertad, así en su conversación con Víctor, afirma tajante: "Yo me iría muy lejos" (Acto segundo, Cuadro segundo, p. 85). O algo después, en el Cuadro primero del Acto tercero,
Yerma sentencia: "Yo pienso que tengo sed y no tengo libertad" (p. 92).

A ello se une en Yerma su constante angustia vital, su obsesivo deseo de maternidad. Desde el comienzo de la obra, Yerma -cuyo nombre propio ya muestra su conflicto personal- evidencia pues su drama existencial. Así, en el Cuadro primero del Acto primero, Yerma canta una bella canción que se asemeja a una nana, y así declama expresando su deseo de ser madre: "'Te diré, niño mío, que sí, / tronchada y rota soy para ti. / iCómo me duele esta cintura/ donde tendrás primera cuna! / ¿Cuándo, mi niño, vas a venir? /Cuando tu carne huela a jazmín/ iQué se agiten las ramas al sol/ y salten las fuentes alrededor!" (p. 45).

Más adelante, afirma con rotundidad: “...Cada mujer tiene sangre para cuatro o cinco hijos y cuando no los tienen se les vuelve veneno, como me va a pasar a mí" (Acto primero, Cuadro primero, p. 50). Ante el deseo frustrado de maternidad de Yerma, su marido Juan le propone que crie un hijo de su hermano, a lo que Yerma responde: "No quiero cuidar hijos de otros. Me figuro que me van a helar los brazos de tenerlos" (Acto segundo, Cuadro segundo, p. 78). Yerma sólo verá realizado su deseo de maternidad si engendra un hijo; por ello, bellamente le expresa así su frustración a su marido Juan, quien no sabe comprenderla: "Quiero beber agua y no hay vaso ni agua, quiero subir al monte y no tengo pies, quiero bordar mis enaguas y no encuentro los hilos" (Acto segundo, Cuadro segundo, p. 78).

Este afán frustrado de maternidadlleva a Yerma al desvarío: "Acabaré creyendo que yo misma soy mi hijo. Muchas veces bajo yo a echar la comida a los bueyes, que antes no lo hacía, porque ninguna mujer lo hace, y cuando paso por lo oscuro del cobertizo mis pasos me suenan a pasos de hombre" (Acto segundo, Cuadro segundo, p. 82). Debido a su situación, Yerma acude con su marido a una romería para pedir al Santo que le dé hijos pronto. Allí, el personaje de la Vieja, le dice que la culpa de no haber concebido ya un hijo es de su marido Juan: “...La culpa es de tu marido. ¿Lo oyes? Me 
dejaría cortar las manos. Ni su padre, ni su abuelo, ni su bisabuelo se portaron como hombres de casta. Para tener un hijo ha sido necesario que se junte el cielo con la tierra. Están hechos con saliva. En cambio, tu gente no. Tienes hermanos y primos a cien leguas a la redonda. Mira qué maldición ha venido a caer sobre tu hermosura" (Acto tercero, Cuadro segundo, p. 107).

Al final del drama, llega la única realización de la Justicia que para Yerma es posible. Su marido Juan ha escuchado las palabras de la Vieja, y dolido le confiesa en la romería que ambos son estériles, y que nunca podrán concebir un hijo. Así, cuando Juan se acerca a Yerma para besarla, ésta lo mata estrangulándolo, y pronuncia estas palabras finales: "Voy a descansar sin despertarme sobresaltada, para ver si la sangre me anuncia otra sangre nueva. ...No os acerquéis, porque he matado a mi hijo, iyo misma he matado a mi hijo!" (Acto tercero, Cuadro segundo, p. 111).

Este final representa una solución justa, restauradora, sanadora de su desequilibrio y desasosiego personal, que traerá, al menos, la paz a su vida. Su idea de lo justo contrasta con lo justo legal. A través del asesinato de su esposo, Yerma cree hallar el final de su sufrimiento y la compensación de su frustrante situación como mujer. Es más, en esta escena final de la obra queda "establecida fatalmente la separación entre acto sexual y procreación, al señalarse la esterilidad de cada uno de los cónyuges", con lo cual cuando "Juan busca a Yerma, ella se siente ultrajada y reacciona estrangulándolo". (Gil, 1983, pp. 30-31)

\subsubsection{La Casa de Bernarda Alba (1936)}

La Casa de Bernarda Alba (1936) (García Lorca F. , La Casa de Bernarda Alba, 1976) fue la última obra de la producción teatral de Federico García Lorca, debido al fatal desenlace que,con ocasión del estallido de la guerra civil, malogró su vida. Se trata de un drama lorquiano de gran madurez creativa, en donde aparece otra vez con gran crudeza la contraposición entre una justicia natural y una justicia legal o como se ha afirmado, el conflicto entre la ley natural y la ley social (Josephs, A. y Caballero, J., 1976, pág. 19).

La mujer, una mujer fuerte, es en esta obra de nuevo el personaje protagonista. Hay elementos comunes con las tragedias anteriores de Lorca, tales como el universo femenino ubicado en el ambiente rural de la época, el ansia de libertad, los férreos convencionalismos sociales, el honor, la honra, la virginidad, el matrimonio, la muerte, el destino, el fatalismo, y un sentido natural de justicia que marcará el trágico final. En La Casa de Bernarda Alba, al igual que en las anteriores tragedias rurales comentadas, Yerma y Bodas de Sangre, la mujer aparece sometida al sombrío código moral de su mundo social (Barea, 1956, p. 55).

El drama lleva por subtítulo "Drama de mujeres en los pueblos de España". La figura de la mujer que se rebela frente a su inexorable destino ocupa el espacio central del argumento. No obstante, algunos críticos han señalado que esta obra tiene una intención política, y creen ver en ella una clara predicción de la guerra civil española, mientras que otros críticos sostienen que representa esencialmente a todas las mujeres españolas (Josephs, A. y Caballero, J., 1976, p. 73).

Bernarda, mujer viuda con cinco hijas (Amelia, Angustias, Adela, Martirio, Magdalena), es autoritaria, represiva y severa, y representa la ley social más rigurosa. Mientras que su hija menor Adela, quien representa la libertad y la ley natural (Josephs, A. y Caballero, J., 1976, p. 95), pretende romper con los convencionalismos sociales, pagando al final con su propia vida.

La trama argumental de la obra viene marcada por la sobriedad del luto. La obra se inicia con una muerte, la del marido de Bernarda, y termina con otra, la de su hija Adela, y todo transcurre dentro de una casa, la de la matriarca Bernarda Alba, que está cerrada al mundo (Josephs, A. y Caballero, J., 1976, pp. 99-100). Así, Bernarda exclama: “...En ocho años que dure el luto no ha de entrar en esta casa el viento de la calle. Hacemos cuenta que hemos tapiado con ladrillos 
puertas y ventanas. Así pasó en casa de mi padre y en casa de mi abuelo. Mientras, podéis empezar a bordar el ajuar. En el arca tengo veinte piezas de hilo con el que podréis cortar sábanas y embozos. ..." (Acto primero, pp. 128-129).

A lo que se añade que Bernarda quiere siempre imponer su voluntad y ejercer una gran dominación sobre sus hijas: "Aquí se hace lo que yo mando. Ya no puedes ir con el cuento a tu padre. Hilo y aguja para las hembras. Látigo y mula para el varón. Eso tiene la gente que nace con posibles" (Acto primero, p. 129) o cuando más adelante afirma dirigiéndose a sus hijas: "No os hagáis ilusiones de que vosotras vais a poder conmigo. iHasta que salga de esta casa con los pies delante mandaré en lo mío y en lo vuestro!" (Acto primero, p. 144).

La obsesión de Bernarda por custodiar la honra de su casa y la de sus hijas, que es la suya propia, vertebra la obra por completo: "iCuánto hay que sufrir y luchar, para hacer que las personas sean decentes y no tiren al monte demasiado!" (Acto primero, p. 133). En el Acto tercero, Bernarda afirma: "Cada uno sabe lo que piensa por dentro. Yo no me meto en los corazones, pero quiero buena fachada y armonía familiar..." (p. 182). Bernarda ejerce,en consecuencia, una dominación absoluta sobre el futuro sentimental de sus hijas: "iNo ha tenido novio ninguna ni les hace falta! Pueden pasarse muy bien. ... No hay en cien leguas a la redonda quien se pueda acercar a ellas. Los hombres de aquí no son de su clase. ¿Es que quieres que las entregue a cualquier gañán?" (Acto primero, p. 134).

Las hijas de Bernarda se han convertido en víctimas de los férreos planteamientos morales de su madre y de su intransigente ley social, y están siempre temerosas de lo que pueda comentarse sobre ellas en el pueblo. Así, Amelia dice: "De todo tiene la culpa esta crítica que no nos deja vivir" o Magdalena comenta "nos pudrimos por el que dirán" (Acto primero, pp. 135 y 137). La hija menor de Bernarda, Adela, se rebela frente a estos planteamientos $y$, rompiendo a llorar con ira, manifiesta su ansia de libertad: "No me acostumbraré. Yo no puedo estar encerrada. No quiero que se me pongan las carnes como a vosotras; no quiero perder mi blancura en estas habitaciones; mañana me pondré mi vestido verde y me echaré a pasear por la calle. iYo quiero salir!" (Acto primero, p. 142). O cuando oye salir a los hombres del pueblo para volver al campo a trabajar, exclama: "iAy, quién pudiera salir también a los campos!" (Acto segundo, p. 159). Más adelante, afirma rotunda: "Mi cuerpo será de quien yo quiera" (Acto segundo, p. 154).

Sin embargo, falta un elemento esencial para que se desencadene el fatídico final. Las habladurías del pueblo dicen que Pepe el Romano pretende a la hija mayor de Bernarda Alba, Angustias; sin embargo, Adela está enamorada de él, y en el drama se insinúa que por las noches se ve asolas con dicho joven. Los deseos de libertad de Adela le hacen saltar sin miedo por encima de la moral socialmente establecida y decir: "Ya no aguanto el horror de estos techos después de haber probado el sabor de su boca. Seré lo que él quiera que sea. Todo el pueblo contra mí, quemándome con sus dedos de lumbre, perseguida por los que dicen que son decentes, y me pondré la corona de espinas que tienen las que son queridas de algún hombre casado" (Acto tercero, p. 195).

La criada Poncia atormentada por la falta de libertad que se respira en la casa, por la dominación a la que Bernarda somete a sus hijas, por las maniobras insidiosas de Martirio,y por la rebeldía de Adela, pronuncia las siguientes palabras: "A mí me gustaría cruzar el mar y dejar esta casa de guerra". (Acto tercero, p. 189).

Esta situación de conflicto llega a conocimiento de Bernarda, que intenta imponer su sentido de justicia intentando matar a tiros con una escopeta a Pepe el Romano después de haber visitado a Adela una noche (Acto tercero, p. 197). Adela, que lo cree muerto, se suicida ahorcándose, mientras su madre Bernarda al descubrir su cadáver, dirá: “...Pepe, tú irás corriendo vivo por lo oscuro de las alamedas, pero otro día caerás. iDescolgarla! iMi hija ha muerto virgen! Llevadla a su cuarto 
y vestirla como una doncella. iNadie diga nada! Ella ha muerto virgen. Avisad que al amanecer den dos clamores las campanas" (Acto tercero, p. 199). La fortaleza de carácter de Bernarda Alba se refleja en las últimas palabras con las que cierra el drama: "Y no quiero llantos". La muerte hay que mirarla cara a cara. iSilencio! iA callar he dicho!iLas lágrimas cuando estés sola! Nos hundiremos todas en un mar de luto... ¿Me habéis oído? iSilencio, silencio he dicho! iSilencio!." (Acto tercero, p. 199).

El entendimiento de la justicia como venganza se refleja de nuevo en el final de la obra, cuando Bernarda quiere cobrarse con la vida del joven pretendiente para salvar su honor. Este frustrado intento de asesinato muestra hasta donde este personaje lorquiano es capaz de llegar con tal de ver realizado su particular sentido de justicia. Por su parte, el suicidio de su hija menor, Adela, supone la realización de la justicia mediante la superación liberadora y restauradora de una situación de sufrimiento.

En efecto, el suicidio de Adela en La Casa de Bernarda Alba y el asesinato de Juan a manos de su esposa en Yerma o la muerte del Novio a manos de Leonardo, auspiciada por la Madre, en Bodas de Sangre, representan sendas muestras del particularísimo sentido de justicia natural de tres personas que viven atormentadas, y que encuentran en la venganza el resarcimiento de todo su intenso dolor. Adela, por un amor imposible, por el que es a la par víctima de la moral social imperante; Yerma, por su frustrado

4 La fortaleza de la mujer, que es prototipo de los dramas lorquianos, es tan extrema que le lleva a reprimir incluso el propio llanto ante la tragedia. En Bodas de Sangre, encontramos en boca de la Madre unas palabras muy parecidas a las aquí transcritas que pronuncia Bernarda Alba. En efecto, en Bodas de Sangre, en el Cuadro último del Acto tercero, la Madre tras descubrir que su hijo ha fallecido a manos de Leonardo, exclama: "¿Te quieres callar? No quiero llantos en esta casa. Vuestras lágrimas son lágrimas de los ojos nada más, y las mías vendrán cuando yo esté sola, de las plantas de mis pies, de mis raíces y serán más ardientes que la sangre". (2012-2017, p. 125). deseo de maternidad que le impide realizarse plenamente como mujer; y la Madre de Bodas de Sangre, que empuja a su propio hijo hacia la muerte, por salvar la honra de su familia. En sus dramas, Lorca lleva a sus personajes a situaciones extremas, los aboca a la muerte. Pues sólo a través de un trágico final que se anuncia como irreversible e irresoluble desde el mismo comienzo de la trama, esa mujer fuerte que ansía libertad puede ver realizada la justicia, al menos la justicia que entiende como natural, en su propia existencia.

Federico García Lorca se muestra como un profundo conocedor de la España de su época, primer tercio del siglo XX, y en concreto de la tierra andaluza donde nació y encontraría la muerte. Se ha apuntado acertadamente que la Andalucía que Lorca refleja en sus obras es "esa otra Andalucía, esa milenaria y, a veces, bastante oculta Andalucía que se extiende por lo menos desde tiempos del legendario Gerión tartéssico hasta nuestros días, y de la cual Lorca ha llegado a ser nada menos que su mejor intérprete."(Josephs, A., y Caballero, J., 1977, p. 21)

\section{CONCLUSIONES}

Desconocemos por qué Federico García Lorca lleva a sus personajes femeninos a estas situaciones de intensidad dramática. Lo que sí sabemos, porque lo hemos mostrado en estas páginas, es que en sus dramas principales aparecen reiteradamenteunas constantes expresivas para trazar el argumento que se propone transmitir al lector. Tales constantes expresivas nos llevan a afirmar la presencia de una unidad temática que dota de completa significación a su obra teatral.

Al utilizar tales constantes quizás pudiéramos pensar que la intención última de Federico García Lorca es de denuncia política y social. Es decir,nos describe unos caracteres que siempre están tomados de hechos reales y que decide cubrir de un bello ropaje literario, pero que representan unos valores propios de un modelo 
estructural de sociedad arraigado en la España de su tiempo que él, en el fondo, rechaza. Sin embargo, sea cual sea su intención última, lo cierto es que vuelca su personalidad creativa en unas preocupaciones temáticas muy concretas. En efecto, aspectos como la condición femenina y su distinción del universo masculino, la reivindicación de su dignidad, su pretendida libertad y su sentido de justicia, son elementos que sin duda están obsesivamente presentes en su obra.

Asumiendo una perspectiva sociológica y filosófico-jurídica, hemos tratado de averiguar, como objetivo último de nuestro empeño metodológico, el profundo sentido de lo justo que anida en sus dramas. El eterno conflicto entre lo justo natural y lo justo legal, que fuera ya magistralmente enunciado por Aristóteles en el libro V de Ética a Nicómaco(Aristóteles, 1970), vértebra, a nuestro parecer, el correcto entendimiento de la trama argumental principal de sus obras. Cuando el estagirita explicaba que la justicia natural es aquella que "tiene en todas partes la misma fuerza, independientemente de que lo parezca o no, y legal la de aquello que en un principio da lo mismo que sea así o de otra manera, pero una vez establecido ya no da lo mismo" (Ét. a Nic., L. V, c. 7, 1134b 20), nos daba ya la clave certera para la distinción entre lo que siempre es válido en cualquier tiempo y lugar, porque nace de la razón humana y de su dignidad, y aquello que puede sermeramente producto arbitrario de la voluntad caprichosa del que ejerce el poder.

Los personajes lorquianos parecen debatirse constantemente entre la ley natural y la ley social, entre lo eternamente válido por naturaleza $y$ aquello que es fruto de las imposiciones y los convencionalismos sociales. Este dilema se convierte en auténtico drama existencial de esas mujeres fuertes ansiosas de libertad en que el poeta granadino magistralmente se recrea.

No obstante, el entendimiento de la justicia es a veces complejo en la obra dramática lorquiana. Unas veces lo justo se identifica con férreos convencionalismos sociales y se torna venganza; en otras, la justicia es libertad, y en muchas ocasiones el único camino de llegar a ella es el de la muerte como liberalización de una situación frustrante. Mariana Pineda, la heroína de la libertad, es capaz de entregar su propia vida, en nombre de la bandera de la libertad que ella misma ha bordado, ante una sentencia injusta y cumplir así con su código moral; la Madre de Bodas de Sangre, es capaz de empujar a su único hijo vivo a la muerte con tal de salvar la honorabilidad de su estirpe y cumplir con las convenciones sociales; la joven Yerma, que movida por su desvarío psicológico, da muerte a su esposo Juan, desafiando la ley penal positiva pero sintiendo realizada la justicia reparadora en su frustrante existencia personal diaria; y Adela, la hija de la tiránica matriarca Bernarda Alba, nos muestra una valentíatal que le llevará hasta el suicidio como liberación y rebeldía frente a la dominación que padece y lainjusticia cometida por su madre al intentar asesinar a su amante con tal de imponer su particular ley moral.

Esa búsqueda incansable de la justicia de los personajes de los dramas lorquianos no es, sin embargo, en el fondo, una búsqueda libre, sino determinada por el fatalismo. Desde el inicio mismo de la obra, los personajes están condicionados por unos acontecimientos previos que ellos no han propiciado ni elegido. El propio título de sus obras avala esta idea. Mariana Pineda es un personaje histórico que fue ejecutado por el absolutismo de Fernando VII, con lo cual el lector conoce de antemano la sentencia injusta a la que Mariana habrá de enfrentarse; la joven protagonista de Yerma lleva en su nombre propio inscrita la fatalidad de un destino que se niega a aceptar; el título de Bodas de Sangre hace presagiar el fatal desenlace al que el personaje de la Madre del Novio aboca a su único hijo vivo; y La Casa de Bernarda de Alba es expresión del universo cerrado e injusto de su dueña. La justicia que alcanzan los personajes es, pues, la única justicia a la que pueden optar, dado el determinismo que preside sus vidas, pero lo que no se puede cuestionar es su profundo deseo de su más plena realización. 


\section{REFERENCIAS}

Aristóteles. (1970). Ética a Nicómaco. Edición bilingüe y traducción de María Araújo y Julián Marías, introducción y notas de Julián Marías. Madrid: Instituto de Estudios Políticos.

Barea, A. (1956). Lorca, el poeta y el pueblo. Buenos Aires: Losada.

Botero Bernal, A., y Narváez Hernández, J.R., (Coords.). (2010). "A modo de Introducción: Derecho y Literatura, el señor y su amante". En A. Botero Bernal y Narváez Hernández, J.R, Cuentos sobre el Derecho.Buenos Aires: Libros en Red.

Cano, J.L. (1962). García Lorca. Biografía ilustrada. Vitoria: Ediciones Destino-Barcelona.

Cantarella, E. (2007). "Premesa". EnDiritto e Teatro in Grecia e a Roma (pág. 10). A cura di Eva Cantarella e Lorenzo Gagliardi.Milano: Edizioni Universitarie di Lettere Economia Diritto.

Celemín Santos, V. (1996). El Derecho en la literatura medieval.Barcelona: Bosch Casa Editorial.

De Los Ríos Urruti, F. (1997). El sentido humanista del socialismo. En F. De Los Ríos Urruti, Obras Completas, II (pág. 294). Edición de T. Rodríguez de Lecea.Madrid: Fundación Caja de Madrid y Anthropos Editorial.

Elías de Tejada, F. (1977). Tratado de Filosofía del Derecho, II.Sevilla: Secretariado de Publicaciones de la Universidad de Sevilla.

Estrabón. (1995). Geografía (Hispania y Galia). Introducciones, Traducción y Notas $\mathrm{M}^{\mathrm{a}}$ José Meana (Libro III) y Félix Piñero (Libro IV). Barcelona: Planeta.

G. De Valdeavellano, L. (1981). "Prólogo". En A. Posada, Breve Historia del Krausismo español (págs. 11-13 y 20). Oviedo: Servicio de Publicaciones de la Universidad de Oviedo.

Ganivet, A. (1943). Idearium español (Obras Completas, I).Madrid: Aguilar.
Gaos, V. (1977). "Introducción". En Antología del Grupo poético de 1927 (pág. 13). Edición de Vicente Gaos actualizada por Carlos Sahagún. Madrid: Cátedra.

García López, J. (1983). Historia de la Literatura Española.Barcelona: Vicens Vives.

García Lorca, F. (1976). La Casa de Bernarda Alba.Edición de Allen Josephs y Juan Caballero. Madrid: Cátedra.

García Lorca, F. (1983). Yerma. Poema trágico en tres actos y seis cuadros. Edición de IldefonsoManuel Gil.Madrid: Cátedra.

García Lorca, F. (1984). Mariana Pineda. Romance popular en tres estampas. Madrid: Colección Austral, Espasa-Calpe.

García Lorca, F. (1986). Bodas de Sangre (Edición, Introducción, notas, comentarios y apéndice de Tomás Rodríguez).Madrid: Anaya.

García Lorca, F. (1991). "Mariana Pineda en Granada”. En F. García Lorca, Obras Completas, III (Recopilación, cronología, bibliografía y notas de Arturo del Hoyo) (págs. 413-415). México: Aguilar.

García Lorca, F. (1991). "Poemas sueltos”. En F. García Lorca, Obras Completas, I (Recopilación, cronología, bibliografía y notas de Arturo del Hoyo, Prólogo de Jorge Guillén).MadridMéxico: Aguilar.

García Lorca, F. (1991). Obras Completas:

Tomo I, Recopilación, cronología, bibliografía y notas de Arturo del Hoyo, Prólogo de Jorge Guillén. México: Aguilar.

Tomo II, Recopilación, cronología, bibliografía y notas de Arturo del Hoyo, Prólogo de Vicente Aleixandre. México: Aguilar.

Tomo III, Recopilación, cronología, bibliografía y notas de Arturo del Hoyo. México: Aguilar.

García Montero, L. (1984). "Poeta y Amigo: Un caso extraño". En R. Alberti, Federico García Lorca, Poeta y Amigo (pág. 38). Granada: Biblioteca de la Cultura Andaluza. 
Gibson, I. (1986). Granada, 1936. El asesinato de García Lorca. Barcelona: Círculo de Lectores, edición especial por cortesía de Editorial Crítica.

Gil Cremades, J. (1999). "La dimensión política del Krausismo en España”. Boletim da Faculdade de Direito, Studia Iuridica, 45, Colloquia-4/99, Universidade de Coimbra, Coimbra Editora., 31-56; vid. págs. 48-49.

Gil, I. (1983). "Introducción". En F. García Lorca, Yerma. Poema trágico en tres actos y seis cuadros (pág. 27). Madrid: Cátedra.

Gómez García, J.A. (2005). "Derecho, Vida y Derecho Vivo en el pensamiento iusfilosófico de Eugen Ehrlich". En E. Ehrlich, Escritos sobre Sociología y Jurisprudencia (pág. 11). Traducción, notas y estudios preliminares de J.A. Gómez García, J.L. Muñoz de Baena, G. Robles Morchón. Madrid-Barcelona: Marcial Pons.

Guillén, J. (1991). "Prólogo: Federico en Persona". En F. García Lorca, Obras Completas, I (págs. XXXI-XXXIV). Recopilación, cronología, bibliografía y notas de Arturo del Hoyo, Prólogo de Jorge Guillén.Madrid-México: Aguilar.

Gurvitch, G. (2001). Elementos de Sociología Jurídica. Edición y Estudio preliminar a cargo J.L. Monereo Pérez. Granada: Comares.

Jongen, F., \& Lemmens, K.,(2007). "AvantPropos". En F.. Jongen\& K. Lemmens, Droit \& Littérature (págs. 9-12).Sous la direction de François Jongen et Koen Lemmens, Préface de François Ost.Louvain-la-Neuve: Anthemis.

Josephs, A., y Caballero, J. (1977). "Andalucía: Tema y visión" (Introducción). En F. García Lorca, Poema del Cante Jondo y Romancero Gitano (pág. 21).Edición de Allen Josephs y Juan Caballero.Madrid: Cátedra.

Josephs, A., y Caballero, J., (1976). "Introducción". En F. García Lorca, La Casa de Bernarda Alba (pág. 19).Edición de Allen Josephs y Juan Caballero.Madrid: Cátedra.

Lorca Navarrete, J. (1971). El Derecho en Adolfo Posada. Granada: Departamento de Filosofía del
Derecho, Cátedra Francisco Suárez, Universidad de Granada.

Lorca Navarrete, J. (1973, núm. 15). Adolfo Posada:Teoría del Estado. Anales de la Universidad Hispalense, Publicaciones de la Universidad de Sevilla, Serie Derecho.

Lorca Navarrete, J. (1996). "La Filosofía Jurídica Española Contemporánea”. En G. Fassò, Historia de la Filosofía del Derecho, III, Siglos XIX y XX (Traducción de J.F. Lorca Navarrete) (pág. 297). Madrid: Pirámide.

Lorca Navarrete, J. (2008). Temas de Teoría y Filosofía del Derecho. $5^{\text {a }}$ Edición, revisión, puesta al día y ampliación de la presente edición por $\mathrm{M}^{\mathrm{a}}$ Isabel Lorca Martín de Villodres.Madrid: Pirámide.

Lorca Navarrete, J.F., y Lorca Martín de Villodres, $M^{\mathrm{a}}$ I. (2002, $2^{\mathrm{a}}$ edic.). Andalucía: Pensamiento jurídico y social. Madrid: Pirámide.

Martín Recuerda, J. (1991, $7^{\text {a }}$ edic.). Las arrecogías del beaterio de Santa María Egipcíaca. Edición de Francisco Ruiz Ramón. Madrid: Cátedra.

Neville Turner, J., \& Williams, P., (Editors). (1994). The Happy Couple, Law \& Literature. Sydney: The Federation Press.

Osorio Morales, J. (1949). Derecho y Literatura. Granada: Secretariado de Publicaciones, Intercambio Científico y Extensión Universitaria (Universidad de Granada).

Puchta. (1828). Das Gewohnheitsrecht .

Reale, M. (1997). Teoría tridimensional del Derecho. Una visión integral del Derecho. Traducción e introducción de Ángeles Mateos. Madrid: Tecnos.

Reina, M. (2012). Los amores oscuros. Madrid: Temas de Hoy.

Rodríguez de Lecea, T. (1997). "Estudio Preliminar a las Obras Completas de Fernando de los Ríos". En F. De Los Ríos Urruti, Obras Completas, Vol. I (Edición de T. Rodríguez de Lecea) (pág. XVII). Madrid: Fundación Caja de Madrid y Anthropos Editorial. 
Rodríguez, T. (1986). "Apéndice". En F. García Lorca, Bodas de Sangre (págs. 141-142). Edición, Introducción, notas, comentarios y apéndice de Tomás Rodríguez. Madrid: Anaya.

Roncagliolo, S. (2012). El amante uruguayo. Una historia real. Alcalá La Real: Alcalá Grupo Editorial.

Sanz Del Río, J. (1857). Discurso pronunciado en la solemne inauguración del año académico de 1857 a 1858 en la Universidad Central.Madrid: Imprenta Nacional.
Sófocles. (1995). Antígona .Traducción y notas de Assela Alamillo.Barcelona: Planeta.

Tomain, J. (2009). Creon's Ghost, Law, Justice and the Humanities. New York: Oxford University Press.

Von Savigny, F. (1977). De la Vocación de nuestro siglo para la Legislación y la Ciencia del Derecho, Traducción del alemán de Adolfo G. Posada, Estudio preliminar sobre El Espíritu del Nuevo Derecho Alemán por el Doctor Enrique de Gandía, Buenos Aires: Editorial Heliasta. 